\title{
SOIL ARTHROPODS IN DIFFERENTLY USED AGROECOSYSTEMS ALONG AN ECOLOGICAL GRADIENT IN SLOVAKIA
}

\author{
Radoslava Kanianska1, Jana Jad'ud'ová1, Miriam Kizekováa , Jarmila \\ Makovníková3, Bernard Šiška4 ${ }^{4}$ Jozef Varga ${ }^{1}$, Nikola Benková ${ }^{1}$ \\ ${ }^{1}$ Faculty of Natural Sciences, Matej Bel University Banská Bystrica, Tajovského 40, 97401 Banská Bystrica, \\ Slovakia \\ ${ }^{2}$ National Agricultural and Food Centre, Grassland and Mountain Agriculture Research Institute, Mládežnícka 36, \\ 97421 Banská Bystrica, Slovakia \\ ${ }^{3}$ National Agricultural and Food Centre, Soil Science and Conservation Research Institute Bratislava, Regional \\ Station Banská Bystrica, Mládežnícka 36, 97421 Banská Bystrica, Slovakia \\ ${ }^{4}$ Faculty of European Studies and Regional Development, Slovak University of Agriculture in Nitra, Tr. A. Hlinku 2, \\ 94976 Nitra, Slovakia
}

Link to this article: https://doi.org/10.11118/actaun202068030507

Received: 27. 4. 2018, Accepted: 8. 6. 2020

To cite this article: KANIANSKA RADOSLAVA, JAĎUĎOVÁ JANA, KIZEKOVÁ MIRIAM, MAKOVNÍKOVÁ JARMILA, ŠIŠKA BERNARD, VARGA JOZEF, BENKOVÁ NIKOLA. 2020. Soil Arthropods in Differently Used Agroecosystems Along an Ecological Gradient in Slovakia. Acta Universitatis Agriculturae et Silviculturae Mendelianae Brunensis, 68(3): 507-518.

\begin{abstract}
Arthropods are part of important functional groups in soil and little is known about their composition in differently used agroecosystems across larger spatial scales. We analysed the qualitative and quantitative structure of soil arthropods with emphasis on ground beetles in different agroecosystems in relation to the various factors (soil physical properties) that Slovakia as a highly diversified country offers. Research was conducted in 4 different soil types (Arenosol, Cambisol, Fluvisol, Leptosol) at 6 study sites located in three different ecological zones with two different land use types (arable land - AL and permanent grasslands - PG). Ten orders of soil arthropods were identified, of which the most abundant was the order Coleoptera, specifically the Poecilus cupreus species in the Carabidae family. The analysis of variance confirmed significant effect of land use type on arthropod number and ecological gradient-on arthropod biomass and soil temperature. The number and biomass of arthropods was nearly twice as high in PG plots compared to AL plots with the exception of two study sites located in sub-mountain and mountain regions with the dominance and proximity of extensive forest and grassland ecosystems. From the ecological gradient point of view, the highest arthropod biomass was recorded in the mountain ecological zone.
\end{abstract}

Keywords: soil arthropod, arable land, permanent grassland, soil physical property

\section{INTRODUCTION}

Soil is one of the most diverse habitats on earth, and provides an immense array of habitats that contain vast and still largely unknown biodiversity. Soil structure is a major driver of adaptation of individual soil organisms, but soil organisms also influence soil structure.
Soil arthropods as ecosystem engineers (Turbé et al., 2010) have impacts on their habitat and often change its chemical, physical and structural properties with impacts on other biota and ecosystem functions (Jones et al., 1994). They can be used as a bio-indicator and for an assessment of the state of the different forms of ecosystem restoration 
(Nakamura et al., 2003, 2007; Madzaric et al., 2018; Roy et al., 2018). The ecosystem services may become diminished or lost as beneficial populations decline, threating the capacity for sustainable food production (Menalled et al., 2007). Insect's abundance and richness are related to other taxa, climate and soil characteristics, thus representing potential target indicators of environmental changes (Cajaiba et al., 2017). Maintaining a healthy and diverse soil community can also buffer natural ecosystems against the damaging impacts of global warming. Small soil animals can limit the effects of climate change (Crowther et al., 2015). In addition, arthropods can reflect the environmental changes caused by agricultural intensification (Knop et al., 2006). They are used to monitor soil health and evaluate the sustainability of land use practices (Rüdisser et al., 2015) in differently managed ecosystems, in intensively used arable land, extensively used permanent grasslands (e.g. Niedobová and Fric, 2014; Meyer et al., 2019) or abandoned orchards (e.g. Psota and Štastná, 2016; Štastná and Psota, 2013). Observations of relations between soil biota and climate-related parameters are also very important especially in the period of global changes.

At the landscape level, different ecosystems coexist in a mosaic. The pattern observed in the mosaic may result from natural variations in the environment and/or human land management. Land cover and land use patterns on earth reflect the interaction of human activities and the natural environment (Alonso-Pérez et al., 2003), and thus understanding land cover/land use and its changes in areas can provide essential information for forming policies regarding socioeconomic development and environmental management (Campbell and Wynne, 2011). Maintaining diversity in a managed ecosystem including agroecosystem is very important. Agricultural practices belong to the main soil biota influencing factor. Rapid changes in land use, driven largely by the intensification of agriculture over the past century, have resulted in widespread declines in species associated with agricultural landscapes (Butler et al., 2007). Therefore, identifying patterns and determinants of species richness is vital and is of fundamental importance to the management and preservation of biological diversity (Bardgett, 2002). Biologically, worked soil often has more organic matter and more plant-available nutrients and water reserves than adjacent soil (Lal, 1988).

The study reports the soil arthropods with the emphasis on ground beetles in differently used agroecosystem of Slovakia with the following objectives; (1) to record different soil arthropod and ground beetle density, biomass and diversity in 4 soil types with two different land use types (arable land and permanent grasslands) located in various agroecosystems along an ecological gradient of Slovakia (lowland, highland and mountain ecological zone), (2) to evaluate variations of soil arthropod and ground beetle density, biomass productivity and diversity in relation to soil physical properties.

\section{MATERIALS AND METHODS}

\section{Site Characteristics}

The investigations were conducted in Slovakia located predominantly in the mountain territory of the Western Carpathian arc, which forms the boundary between important physical and biogeographic zones and several main European watersheds. The altitudinal range of Slovakia is from 95 to $2655 \mathrm{~m}$ in the High Tatras. Lowlands, regions up to $300 \mathrm{~m}$ above sea level cover $40 \%$ and uplands, regions above $300 \mathrm{~m}$ above sea level cover $60 \%$ of the Slovak territory. Highlands are regions between 300 and $600 \mathrm{~m}$ above sea level and mountain regions lie above $600 \mathrm{~m}$ above sea level. The climate of Slovakia is temperate but is influenced locally by elevation and type of relief. Communities vary from thermophilous in the southern parts of the country, to mountainous at higher altitudes. The geological structure of the Slovak territory is very heterogeneous. Thus the diversity of soils in Slovakia reflects the landscape and rock diversity.

Because of the highly diversified land territory of Slovakia, six study sites located in different ecological zones (three study sites in the lowland ecological zone, two study sites in the highland ecological zone, and one study site in the mountain ecological zone), each with two different land use type plots (one plot used as arable land - AL, the second plot used as permanent grasslands - PG), were selected (Fig. 1, Tabs. I, II). They are located between the altitudes of $121 \mathrm{~m}$ and $950 \mathrm{~m}$ high in different geographic, climatic conditions of Slovakia, and thus different ecological zones. Here we performed a sampling in differently used agroecosystems that span a latitude and ecological gradient in Slovakia (Fig. 1). Ecological gradients are measures of the physical environment that explain the distribution of organisms and ecosystems in terms of environmental tolerances. Commonly used ecological gradients include air temperature, precipitation, soil fertility, soil acidity, moisture regime, and frequency of natural disturbances such as fire, wind, or infestations (Zelazny et al., 2007).

The agricultural plots differ among themselves by land-use intensity. The study sites located at lowland ecological zone (NV, DV, MJ) were more intensively used (higher doses of pesticides and fertilisers, more mechanical operations per year) compared to the study sites located at highland ecological zone (KE, TA). At LT study site located at mountain ecological zone, organic farming was applied. 


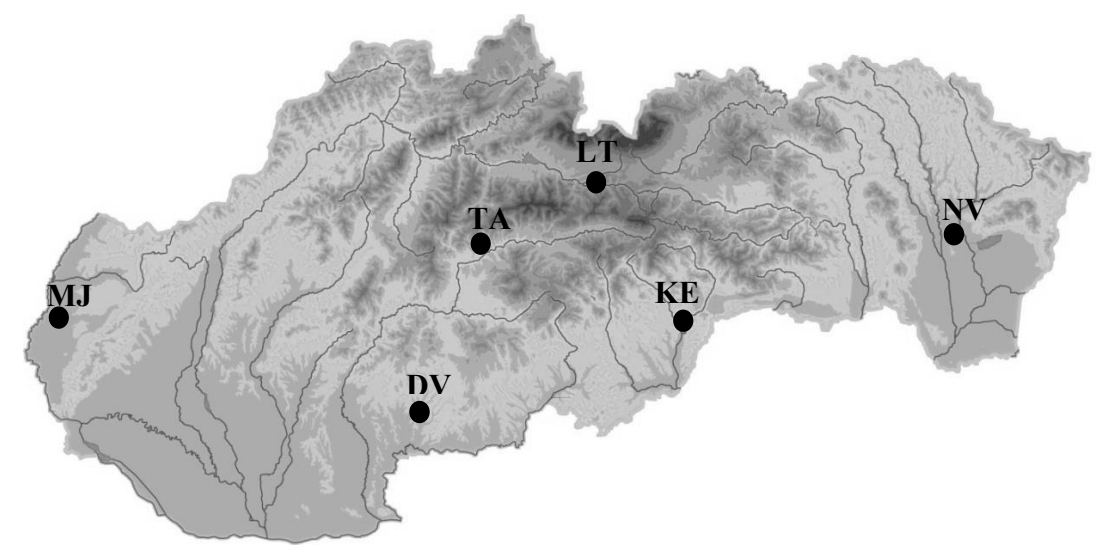

1: Map of the six study sites in Slovakia located in the different ecological zones Abbreviations: NV Nacina Ves, DV Dvorníky, MJ Moravský Ján, KE Kečovo, TA Tajov, LT Liptovská Teplička

I: Site characteristics

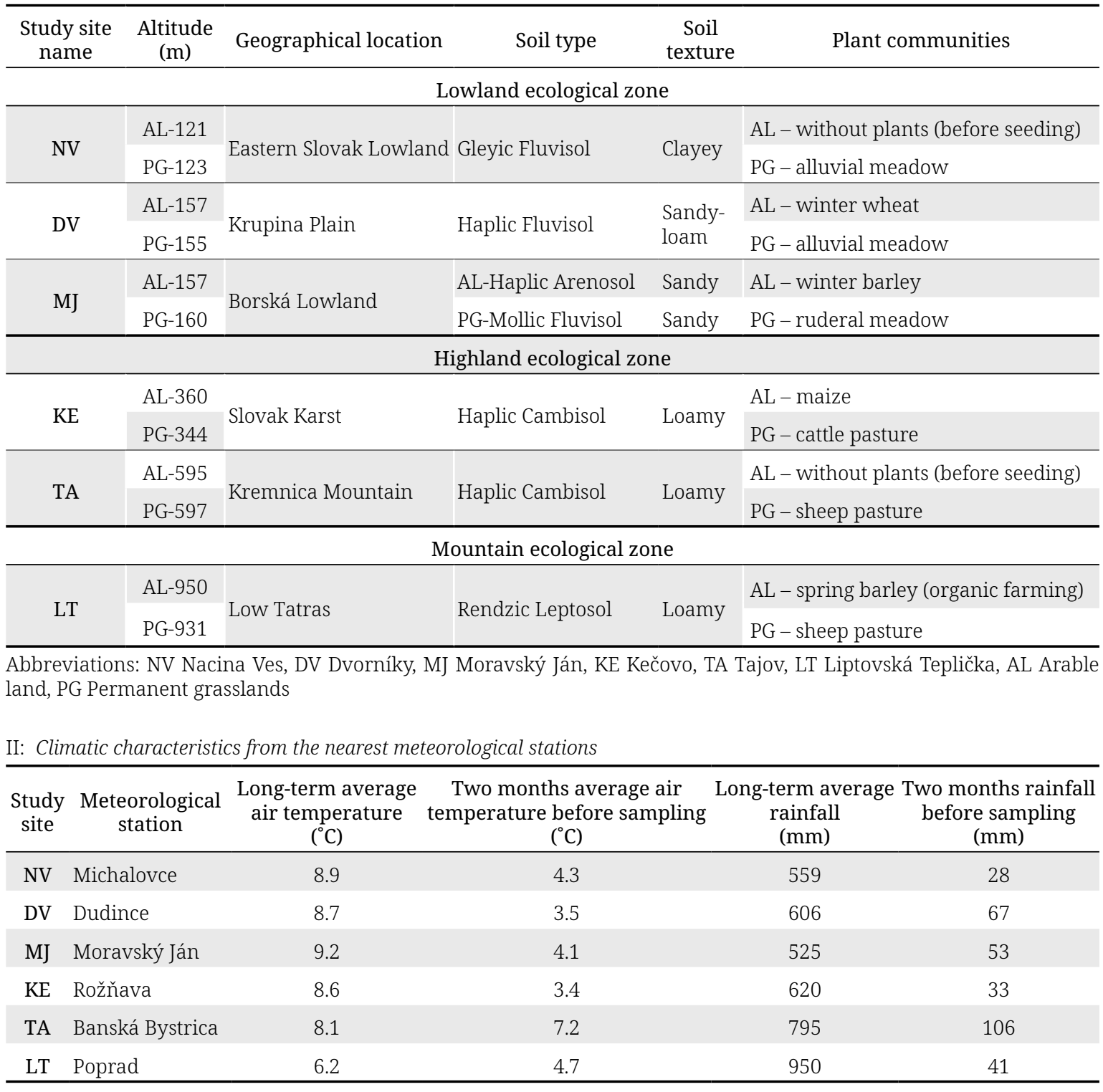

Source: SHMI

Abbreviations: NV Nacina Ves, DV Dvorníky, MJ Moravský Ján, KE Kečovo, TA Tajov, LT Liptovská Teplička 


\section{Soil Arthropods and Ground Beetles Sampling}

The investigations were conducted in the spring of 2015 (March-April) when the edaphon population was starting to be active. Soil arthropods including ground beetles were sampled in six individual study sites with two different land use types (arable land and permanent grasslands). In the randomly placed transect 7 plastic traps were placed flush with the surface of the soil $3 \mathrm{~m}$ apart. The traps were filled with $200 \mathrm{ml}$ formalin solution, which acted as a killing and preserving agent. After one month the traps were collected and the material was weighted. The captured individuals were preserved in formalin solution, identified, and the total number of each one was recorded and classified in taxonomic categories. Quantitative composition was expressed as the number of individuals (ind.trap ${ }^{-1}$ ) and fresh body biomass (g.trap ${ }^{-1}$ ). Eudominant category of the soil arthropod orders and the families of the order Coleoptera was distinguished ( $>1.00$ of the mean number). We calculated arthropod diversity with emphasis on ground beetles. Alfa diversity as average diversity within sampling units (6 study sites with two land uses) was calculated using the Shannon index $\left(\mathrm{H}^{\prime}\right)$. Beta diversity was used to measure the variability in ground beetle species composition in arable land and permanent grasslands at each study site using the Whittaker index. Gama diversity, also called site diversity, was expressed as the total ground beetle species richness at a site.

\section{Soil Measurements}

Before the arthropods sampling, measurements of physical properties were done in the same places where traps were installed. Soil temperature, soil moisture and penetration resistance were measured on each site in seven points of the arable land and permanent grasslands. Soil temperature (ST) was measured at depths of 0.05 by inserting a thermometer in ${ }^{\circ} \mathrm{C}$. Soil moisture level (SM) was measured at depths of $0.05 \mathrm{~m}$ by a soil moisture sensor (ThetaProbe), expressed as a soil moisture volume percentage by measuring the changes in the dielectric constant. Penetration resistance (PR) was measured with an electronic penetrometer (Eijkelkamp Penetrologger) with a cone diameter of $1 \mathrm{~cm}^{2}$ and a $60^{\circ}$ top angle cone. Cone resistance was recorded in $\mathrm{MPa}$ per $0.20 \mathrm{~m}$ of soil depth. Average values were used as soil physical status characteristics.

\section{RESULTS}

\section{Soil Arthropod Biomass, Density and Diversity in Differently Used Agroecosystems Along an Ecological Gradient with Two Different Land Use Types}

The qualitative and quantitative composition of soil arthropods was analysed. A total of 3,943 individuals were trapped representing an overall fresh biomass of $294.5 \mathrm{~g}$. The mean number of soil arthropods per 1 trap at 6 individual study sites spanning an ecological gradient from the lowland to the mountain ecological zone ranged from 26.20 (at NV) to 77.00 ind.trap ${ }^{-1}$ (at MJ). The number of arthropods per 1 trap ranged from 0 to 96 ind.trap $^{-1}$ and from 4 to 273 ind.trap ${ }^{-1}$ in AL and PG, respectively. Within AL plots, the highest mean number of arthropods per 1 trap was recorded at KE in Haplic Cambisol (45.00 ind.trap ${ }^{-1}$ ) and the lowest at NV in Gleyic Fluvisol (15.86 ind.trap ${ }^{-1}$ ). Within PG plots, the highest mean number of arthropods per 1 trap was recorded at MJ in Mollic Fluvisol (112.71 ind.trap ${ }^{-1}$ ) and the lowest at LT in Rendzic Leptosol (23.29 ind.trap ${ }^{-1}$ ) (Tab. III).

On average, the number of arthropods was roughly twice as high in PG plots compared to AL plots at NV, DV, MJ, KE. At TA and LT, the highest located study sites, the number of arthropods was about one-third higher in AL plots compared to PG plots. A similar situation was in the case of the fresh body biomass. Higher arthropod fresh biomass was recorded in PG plots compared to AL plots at NV, DV, MJ, KE. At TA and LT, as in the in case of the number of arthropods, arthropod biomass was higher in AL plots compared to PG plots. The average body biomass of the arthropods per 1 trap ranged from 0

III: Basic statistical characteristics of soil arthropod number at the 6 study sites and with different land use (ind.trap ${ }^{-1}$ )

\begin{tabular}{|c|c|c|c|c|c|c|c|c|c|}
\hline \multirow{2}{*}{ Study site } & \multirow{2}{*}{$\begin{array}{c}\mathrm{AL}+\mathrm{PG} \\
\text { Mean }\end{array}$} & \multicolumn{4}{|c|}{$\mathrm{AL}$} & \multicolumn{4}{|c|}{ PG } \\
\hline & & Min & $\operatorname{Max}$ & Mean \pm SD & Median & Min & Max & Mean \pm SD & Median \\
\hline NV & 26.20 & 0.00 & 25.00 & $15.86 \pm 7.43$ & 19.00 & 22.00 & 55.00 & $36.57 \pm 12.82$ & 33.00 \\
\hline DV & 32.00 & 7.00 & 33.00 & $20.29 \pm 7.80$ & 21.00 & 4.00 & 115.00 & $43.86 \pm 42.24$ & 27.00 \\
\hline MJ & 77.00 & 8.00 & 96.00 & $40.00 \pm 26.25$ & 37.00 & 44.00 & 273.00 & $112.71 \pm 77.64$ & 77.00 \\
\hline $\mathrm{KE}$ & 61.57 & 24.00 & 79.00 & $45.00 \pm 18.81$ & 44.00 & 45.0 & 104.0 & $78.14 \pm 20.50$ & 69.00 \\
\hline TA & 35.43 & 0.00 & 95.00 & $39.43 \pm 32.55$ & 30.00 & 9.00 & 52.00 & $31.43 \pm 14.37$ & 32.00 \\
\hline LT & 28.00 & 2.00 & 74.00 & $32.71 \pm 28.47$ & 12.00 & 8.00 & 40.00 & $23.29 \pm 9.79$ & 23.00 \\
\hline
\end{tabular}

Abbreviations: NV Nacina Ves, DV Dvorníky, MJ Moravský Ján, KE Kečovo, TA Tajov, LT Liptovská Teplička, AL Arable land, PG Permanent grasslands 
to 35.24 g.trap ${ }^{-1}$ and 0.40 to 12.02 g.trap ${ }^{-1}$ in AL plots and PG plots, respectively. Within AL plots, the highest mean body biomass of the arthropods per 1 trap was recorded at LT in Rendzic Leptosol (13.85 g.trap ${ }^{-1}$ ) and the lowest at DV in Haplic Fluvisol (0.31 g.trap $\left.{ }^{-1}\right)$. Within PG plots, the highest mean body biomass of the arthropods per 1 trap was recorded at MJ in Mollic Fluvisol (6.20 g.trap ${ }^{-1}$ ) and the lowest at DV in Haplic Fluvisol (1.13 g.trap $\left.{ }^{-1}\right)$. The average fresh body biomass of the arthropods per 1 trap at the 6 individual study sites spanning an ecological gradient from the lowland to the mountain ecological zone ranged from 0.72 (at DV) to 8.47 g.trap ${ }^{-1}$ (at LT) (Tab. IV).

A total of five classes (Arachnida, Malacostrata, Diploda, Chilopoda, Insecta) and ten orders of soil arthropods were registered. The class Arachnida was represented by the order Araneida, the class Malacostrata by the order Isopoda, the class Diploda by the order Julida, the class Chilopoda by the order Geophilomorpha, and the class Insecta by six orders: Dermaptera, Hemiptera, Orthoptera, Hymenoptera, Diptera, Coleoptera.
In AL plots, a total of 7 orders were identified, of which the highest number of orders were identified at MJ in Haplic Arenosol and at KE in Haplic Cambisol (6 orders) and the lowest number at LT in Rendzic Leptosol (3 orders) (Tab. Va). In PG, a total of 10 orders were identified, of which the highest number of orders were identified at MJ in Mollic Fluvisol and the lowest number at NV in Gleyic Fluvisol and DV in Haplic Fluvisol (5 orders) (Tab. Vb).

Within AL study sites, the maximum orders diversity was found at $\mathrm{KE}$ in Haplic Cambisol $\left(\mathrm{H}^{\prime}=1.32\right)$ and the minimum at LT in Rendzic Leptosol $\left(\mathrm{H}^{\prime}=0.48\right)(\mathrm{Tab} . \mathrm{Va})$. Within PG study sites, the maximum orders diversity was found at MJ in Haplic Fluvisol $\left(\mathrm{H}^{\prime}=1.53\right)$ and the minimum at DV in Haplic Fluvisol ( $\mathrm{H}^{\prime}=$ 0.93) (Tab. Vb).

The dominance of captured arthropod orders ranged from eudominant to subrecedent classes. Within the 6 study sites, these orders belonged to the eudominant class: Coleoptera, Araneida, Hymenoptera, Diptera, Dermaptera. Within AL plots, these orders

IV: Basic statistical characteristics of soil arthropod fresh biomass at the 6 study sites and with different land use (g.trap ${ }^{-1}$ )

\begin{tabular}{|c|c|c|c|c|c|c|c|c|c|}
\hline \multirow{2}{*}{ Study site } & \multirow{2}{*}{$\begin{array}{c}\mathrm{AL}+\mathrm{PG} \\
\text { Mean }\end{array}$} & \multicolumn{4}{|c|}{$\mathrm{AL}$} & \multicolumn{4}{|c|}{ PG } \\
\hline & & Min & $\operatorname{Max}$ & Mean \pm SD & Median & Min & $\operatorname{Max}$ & Mean \pm SD & Median \\
\hline $\mathrm{NV}$ & 2.43 & 0.00 & 4.85 & $2.32 \pm 1.43$ & 2.31 & 0.99 & 5.26 & $2.54 \pm 1.49$ & 1.75 \\
\hline DV & 0.72 & 0.17 & 0.49 & $0.31 \pm 0.09$ & 0.29 & 0.43 & 1.99 & $1.13 \pm 0.60$ & 1.13 \\
\hline MJ & 3.91 & 0.18 & 3.55 & $1.61 \pm 1.00$ & 1.61 & 2.36 & 12.02 & $6.20 \pm 3.51$ & 4.74 \\
\hline $\mathrm{KE}$ & 3.24 & 0.69 & 3.38 & $2.08 \pm 0.79$ & 1.89 & 2.70 & 5.94 & $4.39 \pm 1.25$ & 5.13 \\
\hline TA & 2.28 & 0.00 & 9.21 & $3.02 \pm 3.29$ & 1.19 & 0.40 & 3.35 & $1.53 \pm 0.98$ & 1.32 \\
\hline LT & 8.47 & 0.11 & 35.24 & $13.85 \pm 15.27$ & 1.62 & 1.69 & 3.04 & $3.08 \pm 1.90$ & 2.34 \\
\hline
\end{tabular}

Abbreviations: NV Nacina Ves, DV Dvorníky, MJ Moravský Ján, KE Kečovo, TA Tajov, LT Liptovská Teplička, AL Arable land, PG Permanent grasslands

Va: Summary of the mean numbers of soil arthropod orders (ind.trap ${ }^{-1}$ ) and the Shannon diversity index ( $H^{\prime}$ ) at the 6 study sites in arable land

\begin{tabular}{lccccccc}
\hline \multicolumn{1}{c}{ Order } & $\mathrm{NV}$ & $\mathrm{DV}$ & $\mathrm{MJ}$ & $\mathrm{KE}$ & $\mathrm{TA}$ & $\mathrm{LT}$ & Total \\
\hline Araneida & 1.29 & 3.86 & 6.00 & 18.00 & 2.00 & 2.14 & 6.86 \\
Isopoda & 0.00 & 0.00 & 0.00 & 0.00 & 0.00 & 0.00 & 0.00 \\
Julida & 0.00 & 0.00 & 0.00 & 0.29 & 0.00 & 0.00 & 0.04 \\
Geophilomorpha & 0.14 & 0.00 & 0.29 & 0.00 & 0.00 & 0.00 & 0.06 \\
Dermaptera & 0.00 & 0.00 & 0.00 & 0.00 & 0.00 & 0.00 & 0.00 \\
Hemiptera & 0.00 & 2.43 & 2.14 & 0.29 & 0.00 & 0.00 & 1.07 \\
Orthoptera & 0.00 & 0.00 & 0.00 & 0.00 & 0.00 & 0.00 & 0.00 \\
Hymenoptera & 0.14 & 0.29 & 0.71 & 9.86 & 4.29 & 0.00 & 2.18 \\
Diptera & 1.86 & 1.71 & 25.14 & 3.29 & 10.00 & 2.14 & 6.91 \\
Coleoptera & 12.43 & 12.00 & 7.14 & 13.29 & 23.14 & 28.43 & 18.03 \\
\hline Total & 15.86 & 20.29 & 41.42 & 45.02 & 39.43 & 32.71 & 35.15 \\
H' & 0.73 & 1.15 & 1.14 & 1.32 & 1.05 & 0.48 & 1.29 \\
\hline Abbrevition
\end{tabular}

Abbreviations: NV Nacina Ves, DV Dvorníky, MJ Moravský Ján, KE Kečovo, TA Tajov, LT Liptovská Teplička 
Vb: Summary of the mean numbers of soil arthropod orders (ind.trap ${ }^{-1}$ ) and the Shannon diversity index $\left(H^{\prime}\right)$ at the 6 study sites in permanent grasslands

\begin{tabular}{lccccccc}
\hline \multicolumn{1}{c}{ Order } & $\mathrm{NV}$ & $\mathrm{DV}$ & $\mathrm{MJ}$ & $\mathrm{KE}$ & $\mathrm{TA}$ & $\mathrm{LT}$ & Total \\
\hline Araneida & 5.57 & 3.57 & 37.86 & 42.86 & 13.14 & 8.57 & 18.60 \\
\hline Isopoda & 0.00 & 0.00 & 2.71 & 1.43 & 0.00 & 0.00 & 0.69 \\
\hline Julida & 0.00 & 0.00 & 5.86 & 2.00 & 0.14 & 0.14 & 1.36 \\
Geophilomorpha & 0.00 & 0.00 & 0.14 & 0.14 & 0.00 & 0.14 & 0.07 \\
\hline Dermaptera & 0.00 & 0.00 & 24.86 & 0.86 & 0.00 & 0.14 & 4.31 \\
Hemiptera & 0.29 & 0.14 & 0.29 & 0.00 & 0.43 & 0.00 & 0.19 \\
Orthoptera & 0.00 & 0.00 & 0.00 & 0.29 & 0.43 & 0.00 & 0.12 \\
\hline Hymenoptera & 8.43 & 29.14 & 3.71 & 8.86 & 4.71 & 2.50 & 9.56 \\
Diptera & 2.71 & 1.29 & 2.57 & 1.71 & 4.57 & 2.00 & 2.48 \\
Coleoptera & 19.57 & 9.71 & 34.57 & 20.00 & 8.00 & 10.14 & 17.00 \\
\hline Total & 36.57 & 43.85 & 112.57 & 78.15 & 31.47 & 23.63 & 54.38 \\
H' & 1.19 & 0.93 & 1.53 & 1.26 & 1.42 & 1.25 & 1.57 \\
\hline
\end{tabular}

Abbreviations: NV Nacina Ves, DV Dvorníky, MJ Moravský Ján, KE Kečovo, TA Tajov, LT Liptovská Teplička

belonged to the eudominant class: Coleoptera, Diptera, Araneida, Hemiptera, Hymenoptera. Within PG plots, these orders belonged to the eudominant class: Coleoptera, Araneida, Hymenoptera, Dermaptera.

\section{Ground Beetle Biomass, Density and Diversity in Differently Used Agroecosystems Along an Ecological Gradient with Two Different Land Use Types}

The order Coleoptera belonged to the eudominant class in all study sites and at both different land use types. A total of 1,389 ground beetle individuals were trapped representing an overall biomass of $207.4 \mathrm{~g}$ The number of ground beetles per 1 trap ranged from 0 to 66 ind.trap ${ }^{-1}$ and 0 to 91 ind.trap ${ }^{-1}$ in AL plots and PG plots, respectively. The mean number of ground beetles per 1 trap at the 6 study sites ranged from 10.86 to 20.86 ind.trap ${ }^{-1}$ at DV and MI, respectively. Within AL plots, the highest mean number of ground beetles per 1 trap was recorded at LT in Rendzic Leptosol (28.43 ind.trap ${ }^{-1}$ ) and the lowest at MJ in Haplic Arenosol (7.14 ind.trap ${ }^{-1}$ ). Within PG plots, the highest mean number of ground beetles per 1 trap was recorded at MJ in Mollic Fluvisol (34.57 ind.trap ${ }^{-1}$ ) and the lowest at TA in Haplic Cambisol (8.00 ind.trap ${ }^{-1}$ ). The mean number of ground beetles was higher in PG plots compared to AL plots at NV, MJ and KE. The opposite situation was at DV, TA and LT where the higher mean number of ground beetles was in AL plots compared to PG plots (Fig. 2).

The mean fresh body biomass of ground beetles per 1 trap at the 6 study sites ranged from 0.38 to 7.84 g.trap ${ }^{-1}$ at DV and LT, respectively. Within AL plots, the highest mean body biomass of ground beetles per 1 trap was recorded at LT in Rendzic Leptosol (13.59 g.trap ${ }^{-1}$ ) and the lowest at DV in Haplic Fluvisol (0.141 g.trap $\left.{ }^{-1}\right)$. Within PG plots,

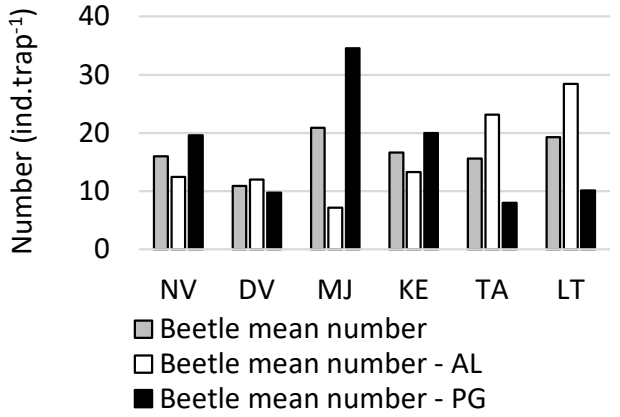

2: Mean number of ground beetles per 1 trap at the 6 study sites and with different land use types (ind.trap ${ }^{-1}$ )

Abbreviations: NV Nacina Ves, DV Dvorníky, MJ Moravský Ján, KE Kečovo, TA Tajov, LT Liptovská Teplička, AL Arable land, PG Permanent grasslands

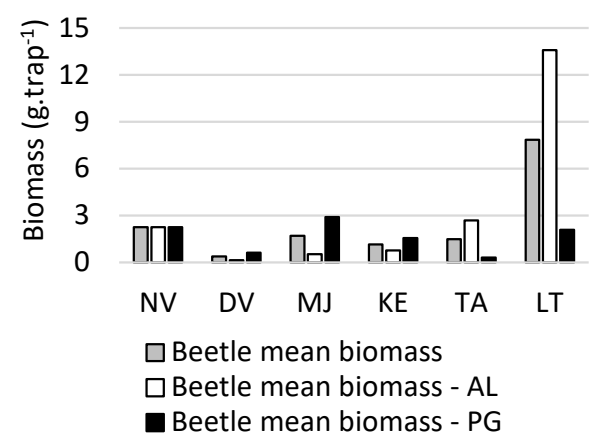

3: Mean fresh body biomass of ground beetles at the 6 study sites and with different land use types (g.trap ${ }^{-1}$ )

Abbreviations: NV Nacina Ves, DV Dvorníky, MJ Moravský Ján, KE Kečovo, TA Tajov, LT Liptovská Teplička, AL Arable land, PG Permanent grasslands 
the highest mean body biomass of ground beetles per 1 trap was recorded at MJ in Mollic Fluvisol (2.89 g.trap $^{-1}$ ) and the lowest at TA Haplic Cambisol $\left(0.31\right.$ g.trap $\left.{ }^{-1}\right)$. The mean biomass of ground beetles was higher in PG plots compared to AL plots at NV, DV, MJ, KE. A different situation was at TA and LT where higher mean biomass of ground beetles was recorded at AL plots compared to PG plots, much like in the case of soil arthropods (Fig. 3).

A total of 32 species of ground beetles from nine families were registered, of which 17 species from seven families in AL plots and 29 species from nine families in PG plots (Tab. VIa, VIb). The dominance of captured families and species ranged from eudominant to subrecedent classes. Within the 6 study sites spanning an ecological gradient from the lowland to the mountain ecological zone, the Carabidae family belonged to the eudominant family at 5 out of 6 study sites. The Chrysomelidae family was missing in all AL plots. The most common species was Poecilus cupreus, a typically predacious species, identified as eudominant at 4 out of 6 study sites. Only 3 species were absent in PG plots (Calandra granaries, Geotrupes stercorarius, Necrophorus vespillo), and 15 in AL plots (Heliotaurus ruficollis, Anchomenus dorsalis, Broscus cephalotes, Lebia cyanocephala, Zabrus tenebrioides, Cassida nebulosi, Cassida viridis, Chaetocnema concinna, Chrysolina coerulans, Cryptocephalus pini, Alophus trigullatus, Anthonomus rubi, Cyphocleonus dealbatus, Silpha obscura, Staphylinus caesareus).
Within AL plots, the maximum alpha ground beetle species diversity in terms of the Shannon index was found at KE in Haplic Cambisol (1.25) and the minimum at TA in Haplic Cambisol (0.49). Within PG plots, the maximum alpha ground beetle species diversity in terms of the Shannon index was found at KE in Haplic Cambisol (1.96) and the minimum at NV in Gleyic Fluvisol (1.12). The maximum gama ground beetle species diversity was found at KE (15) and the minimum at NV (5). The largest beta ground beetle species diversity between pairwise compared AL and PG plots was found at DV (1.00) and the lowest at LT (0.29) (Tab. VII).

\section{Soil Arthropods and Ground Beetles in Relation to Land Use, Ecological Gradient and Soil Properties}

Regarding the results for arthropod number and biomass, significant effect of land use type on arthropod number and ecological gradient on arthropod biomass was observed. There were not observed significant interactions for land use type and ecological gradient for arthropod number as well as for arthropod biomass (two-way ANOVA). Regarding the results for selected soil physical properties measured in the same places where the arthropods were sampled, significant effect of land use type on soil moisture and penetration resistance was observed. There were not observed significant

VIa: Summary of the mean numbers of ground beetle species (ind.trap ${ }^{-1}$ ) at the 6 study sites in arable land

\begin{tabular}{|c|c|c|c|c|c|c|c|c|}
\hline Species & Family & NV & DV & MJ & $\mathrm{KE}$ & TA & LT & Total \\
\hline Abax parallelepipedus & Carabidae & 0.00 & 0.00 & 0.29 & 0.71 & 0.00 & 0.00 & 1.00 \\
\hline Carabus cancellatus & Carabidae & 0.00 & 0.00 & 0.00 & 0.00 & 0.00 & 20.29 & 20.29 \\
\hline Carabus violaceus & Carabidae & 0.00 & 0.00 & 0.00 & 0.00 & 0.00 & 0.86 & 0.86 \\
\hline Pseudophonus rufipes & Carabidae & 7.71 & 0.00 & 0.00 & 0.00 & 0.00 & 0.00 & 7.71 \\
\hline Pterostichus melanarius & Carabidae & 3.86 & 0.29 & 0.00 & 0.00 & 0.00 & 0.00 & 4.15 \\
\hline Cocinella septempunctata & Coccinellidae & 0.00 & 0.00 & 0.86 & 0.00 & 1.86 & 4.00 & 6.72 \\
\hline Sciaphilus asperatus & Curculionidae & 0.00 & 0.00 & 0.00 & 0.43 & 0.00 & 0.00 & 0.43 \\
\hline Epicometis hirta & Scarabaeidae & 0.00 & 0.00 & 0.57 & 0.43 & 0.00 & 0.00 & 1.00 \\
\hline Geotrupes stercorarius & Scarabaeidae & 0.00 & 5.86 & 0.00 & 0.00 & 0.00 & 0.00 & 5.86 \\
\hline Necrophorus vespillo & Silphidae & 0.86 & 0.00 & 0.00 & 0.00 & 0.00 & 0.00 & 0.86 \\
\hline Ocypus tenebricosus & Staphylinidae & 0.00 & 5.71 & 0.00 & 0.00 & 0.00 & 0.00 & 5.71 \\
\hline Opatrum sabulosum & Tenebrionidae & 0.00 & 0.00 & 4.57 & 0.00 & 0.00 & 0.00 & 4.57 \\
\hline
\end{tabular}

Abbreviations: NV Nacina Ves, DV Dvorníky, MJ Moravský Ján, KE Kečovo, TA Tajov, LT Liptovská Teplička 
VIb: Summary of the mean numbers of ground beetle species (ind.trap ${ }^{-1}$ ) at the 6 study sites in permanent grasslands

\begin{tabular}{|c|c|c|c|c|c|c|c|c|}
\hline Species & Family & NV & DV & MJ & $\mathrm{KE}$ & TA & LT & Total \\
\hline Heliotaurus ruficollis & Allecuidae & 5.71 & 0.00 & 0.00 & 0.00 & 0.00 & 0.00 & 5.71 \\
\hline Abax parallelepipedus & Carabidae & 0.00 & 0.00 & 0.00 & 0.00 & 0.14 & 0.00 & 0.14 \\
\hline Anchomenus dorsallis & Carabidae & 0.14 & 0.00 & 0.00 & 0.00 & 0.00 & 0.00 & 0.14 \\
\hline Broscus cephalotes & Carabidae & 0.00 & 0.00 & 0.00 & 0.00 & 0.00 & 0.14 & 0.14 \\
\hline Calathus fuscipes & Carabidae & 0.00 & 0.00 & 0.00 & 1.43 & 0.00 & 0.29 & 1.72 \\
\hline Carabus cancellatus & Carabidae & 0.00 & 0.14 & 0.00 & 0.00 & 0.00 & 2.14 & 2.28 \\
\hline Carabus violaceus & Carabidae & 0.00 & 0.00 & 0.00 & 0.00 & 0.00 & 0.71 & 0.71 \\
\hline Lebia cyanocephala & Carabidae & 0.00 & 0.00 & 0.00 & 0.14 & 0.00 & 0.00 & 0.14 \\
\hline Poecilus cupreus & Carabidae & 0.00 & 0.00 & 17.14 & 6.43 & 1.71 & 1.29 & 26.57 \\
\hline Pseudophonus rufipes & Carabidae & 8.29 & 0.00 & 0.57 & 0.00 & 0.14 & 0.00 & 9.00 \\
\hline Pterostichus melanarius & Carabidae & 5.43 & 0.00 & 0.00 & 0.00 & 0.00 & 0.00 & 5.43 \\
\hline Zabrus tenebrioides & Carabidae & 0.00 & 0.00 & 0.00 & 0.00 & 0.00 & 0.29 & 0.29 \\
\hline Cassida nebulosa & Chrysomelidae & 0.00 & 0.00 & 0.00 & 0.00 & 0.43 & 0.00 & 0.43 \\
\hline Cassida viridis & Chrysomelidae & 0.00 & 0.00 & 0.00 & 0.00 & 0.43 & 0.00 & 0.43 \\
\hline Chaetocnema concinna & Chrysomelidae & 0.00 & 1.29 & 0.00 & 1.57 & 0.43 & 0.00 & 3.29 \\
\hline Chrysolina coerulans & Chrysomelidae & 0.00 & 0.00 & 0.00 & 1.43 & 0.00 & 0.00 & 1.43 \\
\hline Cryptocephalus pini & Chrysomelidae & 0.00 & 0.00 & 1.71 & 1.71 & 0.43 & 1.71 & 5.56 \\
\hline Cocinella septempunctata & Coccinellidae & 0.00 & 0.00 & 0.00 & 0.00 & 0.00 & 1.43 & 1.43 \\
\hline Alophus trigullatus & Curculionidae & 0.00 & 1.14 & 0.00 & 1.57 & 0.00 & 0.00 & 2.71 \\
\hline Anthonomus rubi & Curculionidae & 0.00 & 0.00 & 0.00 & 0.00 & 2.29 & 0.00 & 2.29 \\
\hline Bothynoderes punctiventris & Curculionidae & 0.00 & 0.86 & 0.00 & 0.00 & 0.00 & 0.00 & 0.86 \\
\hline Cleonus piger & Curculionidae & 0.00 & 0.00 & 0.57 & 0.00 & 0.00 & 0.00 & 0.57 \\
\hline Cyphocleonus dealbatus & Curculionidae & 0.00 & 5.43 & 0.00 & 0.00 & 0.00 & 0.00 & 5.43 \\
\hline Sciaphilus asperatus & Curculionidae & 0.00 & 0.00 & 0.00 & 0.71 & 0.00 & 0.00 & 0.71 \\
\hline Epicometis hirta & Scarabaeidae & 0.00 & 0.86 & 5.57 & 0.00 & 0.00 & 0.00 & 6.43 \\
\hline Silpha obscura & Silphidae & 0.00 & 0.00 & 0.00 & 4.29 & 0.00 & 2.14 & 6.43 \\
\hline Ocypus tenebricosus & Staphylinidae & 0.00 & 0.00 & 0.86 & 0.00 & 0.43 & 0.00 & 1.29 \\
\hline Staphylinus caesareus & Staphylinidae & 0.00 & 0.00 & 0.86 & 0.71 & 1.57 & 0.00 & 3.14 \\
\hline Opatrum sabulosum & Tenebrionidae & 0.00 & 0.00 & 7.29 & 0.00 & 0.00 & 0.00 & 7.29 \\
\hline Total & & 19.57 & 9.71 & 34.57 & 20.00 & 8.00 & 10.14 & 101.99 \\
\hline
\end{tabular}

Abbreviations: NV Nacina Ves, DV Dvorníky, MJ Moravský Ján, KE Kečovo, TA Tajov, LT Liptovská Teplička

VII: Alpha, gamma and beta diversity of ground beetle species at the 6 study sites

\begin{tabular}{lccccccc}
\hline \multicolumn{1}{c}{ Order } & NV & DV & MJ & KE & TA & LT & Total \\
\hline Alpha species richness in AL + PG & 1.13 & 1.75 & 1.53 & 2.17 & 1.25 & 1.38 & 2.73 \\
Alpha species richness in AL & 0.84 & 0.85 & 1.13 & 1.25 & 0.49 & 0.89 & 2.22 \\
Alpha species richness in PG & 1.12 & 1.34 & 1.44 & 1.96 & 1.94 & 1.94 & 2.70 \\
Gama species richness & 5 & 10 & 10 & 15 & 12 & 9 & 32 \\
Beta species richness & 0.43 & 1.00 & 0.47 & 0.76 & 0.85 & 0.29 & 0.61 \\
\hline
\end{tabular}

Abbreviations: NV Nacina Ves, DV Dvorníky, MJ Moravský Ján, KE Kečovo, TA Tajov, LT Liptovská Teplička, AL arable land, PG Permanent grasslands 
VIII: Effect of land use type (LUT) and ecological gradient (EG) on the soil arthropod number, the soil arthropod fresh biomass, the soil temperature, the soil moisture and the penetration resistance as analysed by two-way analysis of variance

\begin{tabular}{|c|c|c|c|c|c|c|c|c|c|}
\hline \multirow[t]{2}{*}{ Source of variation } & \multicolumn{3}{|c|}{$\begin{array}{l}\text { LUT } \\
\text { (A) }\end{array}$} & \multicolumn{3}{|c|}{$\begin{array}{l}\text { EG } \\
\text { (B) }\end{array}$} & \multicolumn{3}{|c|}{$\begin{array}{c}\text { Interaction } \\
(\mathrm{A} \times \mathrm{B})\end{array}$} \\
\hline & d.f. & $\mathrm{F}$ & $\mathrm{P}$ & d.f. & $\mathrm{F}$ & $\mathrm{P}$ & d.f. & $\mathrm{F}$ & $\mathrm{P}$ \\
\hline Arthropod number & 1 & 5.271 & 0.024 & 2 & 0.705 & 0.497 & 1 & 0.651 & 0.422 \\
\hline Arthropod biomass & 1 & 0.966 & 0.329 & 2 & 16.272 & 0.000 & 1 & 0.278 & 0.600 \\
\hline Soil temperature & 1 & 0.652 & 0.422 & 2 & 30.387 & 0.000 & 1 & 33.469 & 0.000 \\
\hline Soil moisture & 1 & 55.982 & 0.000 & 2 & 1.020 & 0.365 & 1 & 0.217 & 0.643 \\
\hline Penetration resistance & 1 & 5.114 & 0.026 & 2 & 1.522 & 0.225 & 1 & 0.549 & 0.461 \\
\hline
\end{tabular}

$P$-values highlighted in bold are statistically significant $(\alpha=0.05)$

interactions for land use type and ecological gradient for soil moisture and penetration resistance. In case of soil temperature, significant effect of ecological gradient and interactions of land use type and ecological gradient were observed (Tab. VIII).

\section{DISCUSSION}

We examined how arthropod and ground beetle density, biomass and diversity in Slovak agroecosystems varied across ecological gradients and with different land use types. In our study, a total of 10 orders of soil arthropods were identified, of which the most abundant and eudominant at all study sites was the order Coleoptera. Its family Carabidae belonged to eudominant at all study sites except DV locality where heavy metal contamination was proved (Kobza et al., 2013). On the other hand, the Carabidae family was the most abundant at LT study site at the mountain ecological gradient with organic farming on arable land. This confirmed the findings of many authors who considered Carabidae as indicators of environmental conditions, ecological status or management practices (e.g. Simon et al., 2016; Koivula, 2011).

The analysis of variance showed significant effect of land use type on arthropod number and ecological gradient on arthropod biomass. Soil animals respond to altitudinal, latitudinal or area gradients (Decaens, 2010). It is usually accepted that terrestrial biodiversity decreases with altitude (Gaston, 2000). Within AL plots, the highest number of arthropods was found in the higher ecological zone, at KE study site. The highest arthropod and ground beetle number and biomass were found in the mountain ecological zone, at LT managed as organic farming. At this study site, the lowest beta ground beetle species diversity between pairwise compared AL and PG plots was also found.

Management in general is considered one of the main disturbance factors (Hanson et al., 2017). In arable land, arthropod communities are affected by mechanical alteration of soil, modification of quantity and location of plant residues, and alterations to weed communities (Stinner and House, 1990). Vegetation and crop types also play an important role in arthropod abundance (Osler et al., 2000). Arthropods are sensitive to changes in vegetation and play an important role in the functioning of the agro-ecosystem (Rodríguez et al., 2006). In our research, intensive management practices (tillage and pesticide applications) in AL plots reduced arthropod density and biomass. The number and biomass of arthropods was nearly twice as high in PG plots compared to AL plots of the 6 study sites with the exception of TA and LT study sites. These two study sites are located in mountain regions with the dominance and proximity of extensive forest and grassland ecosystems. The size as well as spatial configuration of these semi-natural habitat patches can be important determinants for sustaining populations and their diversity in arable land and can also lead to a decrease in its local diversity. We observed such an effect in the case of the lowest arthropod and ground beetle species diversity in terms of the Shannon index in AL plots of LT and TA study sites. Regarding the effect of management on soil biota, there are different research results. Many studies reported that extensive or organic management has positive effects on biodiversity (Bentsson et al., 2005; Bingle and McCracken, 1996), but these effects were different for species groups and spatial scales (Batáry et al., 2010). There are also authors who observed no effect of management on selected arthropod orders (Rodríguez et al., 2006; Wiezik, 2010) or they found higher mesofauna abundance in the case of conventional management than in the case of organic one (Schon et al., 2011). In case of carabids, Purtauf et al. (2005) found out that organic and conventional management along a gradient of landscape complexity did not differ within respect to species richness. Surrounding grassland appeared to act as a major source of diversity for farmland carabids.

Intensive management is connected with frequent mechanical operations. Soil compaction affects the habitat of soil organisms by reducing pore size and changing the physical soil environment. 
Due to slower percolation of water in compacted soil, prolonged periods of saturated conditions can occur. Burrowing animals such as ants, beetles can defend themselves better but will still suffer negative effects (Duicker, 2004). The distribution of arthropods in the subsoil depended also on root biomass, total organic carbon content or microbial biomass (Potapov et al., 2017). Soil arthropods diversity could be used as indicator of soil condition in different stratification soil layer (Meitiyani and Dharma, 2019). We observed soil penetration resistance as a surrogate measure for soil compaction. Different tillage regimes can change soil micro-environmental characteristics, which may influence the distribution and abundance of soil arthropods (Xin et al., 2018). The analysis of variance showed significant effect of land use type on penetration resistance. Ploughing, however, may not always be disruptive, as some species may be unaffected and thus able to increase in numbers in the absence of inter-species competition, and as a consequence overall abundance may not differ although the species assemblage may change (Holland and Reynolds, 2002).
Arthropod density, biomass and diversity are strongly influenced by further soil physical and chemical properties. Climate-related soil physical properties are important factors also because of the limited ability of different arthropod orders to regulate body temperature (Bale and Hayward, 2010). Temperature is a key environmental factor affecting life history traits such as the timing of reproduction, egg size and body size, both through evolutionary adaptation as well as phenotypic plasticity (Liefting et al., 2010). In a direct-planting system, crop residues are concentrated at the surface, thus generating a more complex biological system and creating more stable microclimatic conditions with regard to soil humidity and temperature (González Fernándz et al., 1989), which supports a more suitable habitat for soil fauna (Winter et al., 1990). There are predictions that with climate warming, soil temperatures will rise more rapidly in microhabitats within dry soils with sparse plant cover than in moist soils due to differences in thermal capacity (Convey et al., 2003).

\section{CONCLUSION}

Soil arthropods and ground beetles differentiated in density, biomass and diversity along an ecological gradient and under different land use types in Slovak agroecosystems. Our results confirmed that ecological gradient and agricultural land use influence the arthropod and ground beetle composition. But variations presented strong local, taxonomic specificity and land use. Intensive management practices in arable land reduced arthropod density and biomass. Thus arthropod number and biomass were nearly twice as high in permanent grasslands compared to arable land. Two study sites located in mountain and sub-mountain regions with the dominance and proximity of extensive forest and grassland ecosystems were an exception, as they can be determinants for sustaining populations in arable land.

From the ecological gradient point of view, the highest arthropod biomass was recorded in the mountain ecological zone (at LT study site) with the most abundant order Coleoptera, specifically the Carabus cancellatus species from the Carabidae family. The lowest arthropod biomass was recorded in the lowland ecological zone at DV study site with the dominance of the order Hymenoptera. Ten orders of soil arthropods were identified, of which the most abundant was the order Coleoptera, specifically the Poecilus cupreus species in the Carabidae family.

Regarding the results for selected soil physical properties measured in the same places where the arthropods were sampled we found no significant interactions for land use type and ecological gradient for soil moisture and penetration resistance. In case of soil temperature, significant effect of ecological gradient and interactions of land use type and ecological gradient were observed

\section{Acknowledgements}

This work was supported by the Slovak Research and Development Agency under Grant No. APVV0098-12, and by the Scientific Grant Agency of the Ministry of Education, Science, Research and Sport of the Slovak Republic under Grant No. VEGA 1/0767/17. The research of abiotic soil parameters was done by the equipment supported by Operational Programme Research and Development via contract No. ITMS- 26210120024.

\section{REFERENCES}

ALONSO-PÉREZ, F., RUIZ-LUNA, A., TURNER, J., BERLANGA-ROBLES, C. A. and MITCHELSON-JACOB, G. 2003. Land cover changes and impact of shrimp aquaculture on the landscape in the Ceuta coastal lagoon system, Sinaloa, Mexico. Ocean \& Coastal Management, 46(6-7): 583-600. 
BALE, J. S. and HAYWARD, S. A. L. 2010. Insect overwintering in a changing climate. The Journal of Experimental Biology, 213(6): 980-994.

BARDGETT, R. D. 2002. Causes and consequences of biological diversity in soil. Zoology, 105(4): 367-374.

BATÁRY, P., BÁLDI, A., KLEIJN, D. and TSCHARNTKE, T. 2010. Landscape-moderated biodiversity effects of agri-environmental management: a meta-analysis. Proceedings of the Royal Society $B$ : Biological Sciences. 278(1713): 1894-1902.

BUTLER, S. J., VICKERY, J. A. and NORRIS, K. 2007. Farmland biodiversity and the footprint of agriculture. Science, 315(5810): 381-384.

CAMPBELL, J. B. and WYNNE, R. H. 2011. Introduction to remote sensing. New York, London: The Guilford press.

CAJAIBA, R. L., PÉRICO, E., DALZOCHIO, M. S., DA SILVA, W. B., BASTOS, R., CABRAL, J. A. and SANTOS, M. 2017. Does the composition of Scarabaeidae (Coleoptera) communities reflect the extent of land use change in the Brazilian Amazon? Ecological Indicators, 74: 285-294.

CONVEY, P., BLOCK, W. and PEAT, H. J. 2003. Soil arthropods as indicators of water stress in Antarctic terrestrial habitats? Global Change Biology, 9: 1718-1730.

CROWTHER, T. W., THOMAS, S. M., MAYNARD, D. S. et al. 2015. Biotic Interactions Mediate Soil Microbial Feedbacks to Climate Change. Proceedings of the National Academy of Sciences of the United States of America, 122(22): 7033-7038.

DECAENS, T. 2010. Macroecological patterns in soil communities. Global Ecology and Biogeography, 19(3): 287-302.

DUIKER, S. W. 2004. Effects of soil compaction. The Pennsylvania State University.

GASTON, K. J. 2000. Global patterns in biodiversity. Nature, 405: 220-227.

HANSON, H. I., BIRKHOFER, K., SMITH, H. G., PALMU, E. and HEDLUND, K. 2017. Agricultural land use affects abundance and dispersal tendency of predatory arthropods. Basic and Applied Ecology, 18: 40-49.

HOLLAND, J. M. and REYNOLDS, C. J. M. 2003. The impact of soil cultivation on arthropod (Coleptera and Araneae) emergence on arable land. Pedobiologia, 47(2): 181-191.

JONES, C. G., LAWTON, J. H. and SCHACHAK, M. 1994. Organisms as ecosystem engineers. Oikos, 69: 373-86.

KOBZA, J., BARANČÍKOVÁ, G., DODOK, R. et al. 2013. Monitoring and assessment of Slovak soils properties and potential. Interim report. Bratislava: Soil Science and Conservation Research Institute.

KOIVULA, M. J. 2011. Useful model organisms, indicators, or both? Ground beetles (Coleoptera, Carabidae) reflecting environmental conditions. ZooKeys, 100: 287-317.

KNOP, E., KLEIJIN, D., HERZOG, F. and SCHMID, B. 2006. Effectiveness of the Swiss agri-environment scheme in promoting biodiversity. Journal of Applied Ecology, 43: 120-127.

LAL, R. 1988. Effect of macrofauna on soil properties in tropical ecosystems. Agriculture, Ecosystems \& Environment, 24(1-3): 101-116.

LIEFTING, M., WEERENBECK, M., DOOREMALEN, C. and ELLERS, J. 2010. Temperature-induced plasticity in egg size and resistance of eggs to temperature stress in a soil arthropod. Functional Ecology, 24(6): 1291-1298.

MADZARIC, S., CEGLIE, F. G., DEPALO, L. and AL BITAR, L. 2018. Organic vs. Organic - soil arthropods as bioindicators of ecological sustainability in greenhouse system experiment under Mediterranean conditions. Bulletin of Entomological Research, 108(5): 625-635.

MENALLED, F. D., SMITH, R. G., DAUER, J. T. and FOX, T. B. 2007. Impact of agricultural management on carabid communities and weed seed predation. Agriculture, Ecosystems \& Environment, 118(1-4): 49-54.

MEITIYANI and DHARMA, A. P. 2019. Diversity of soil arthropods in different soil stratification layers, the National park of Gede Pangrango Mountain, Cisaurua Resort, West Java, Indonesia. IOP Conf. Series: Earth and Environmental Sciences, 197: 012019.

MEYER, S. T., HEUSS, L., FELDHAAR, H., WEISSER, W. W. and GOSSNER, M. M. 2019. Land-use components, abundance of predatory arthropods, and vegetation height affect predation rates in grasslands. Agriculture, Ecosystems and Environment, 270-271: 84-92.

NAKAMURA, A., PROCTOR, H. and CATTERALL, C. P. 2003. Using soil and litter arthropods to assess the state of rainforest restoration. Ecological Management \& Restoration, 4(1): 20-28.

NAKAMURA, A., CATTERALL, C. P., HOUSE, A. P. N., KITCHING, L. and BURWELL, J. 2007. The use of ants and other soil and litter arthropods as bio-indicators of the impacts of rainforest clearing and subsequent land use. Journal of Insect Conservation, 11(2): 177-186.

NIEDOBOVÁ, J. and FRIC, Z. F. 2014. The adequacy of some collecting techniques for obtaining representative arthropod sample in dry grasslands. Acta Universitatis Agriculturae et Silviculturae Mendelianae Brunensis, 62(1): 167-174. 
OSLER, G. H. R., VAN VLIET, P. C. J., GAUCI, C. S. and ABBOTT, L. K. 2000. Changes in free living soil nematode and micro-arthropod communities under a canola-wheat-lupin rotation in Western Australia. Australian Journal of Soil Research, 38(1): 47-60.

POTAPOV, A. M., GONCHAROV, A. A., SEMENINA, E. E. et al. 2017. Arthropods in the subsoil: Abundance and vertical distribution as related to soil organic matter, microbial biomass and plant roots. European Journal of Soil Biology, 82: 88-97.

PSOTA, V. and ŠŤASTNÁ, P. 2016. Arthropods on abandoned appôe trees: comparison of orchard versus alley. Acta Universitatis Agriculturae et Silviculturae Mendelianae Brunensis, 64(2): 517-526.

PURTAUF, T., ROSCHEWITZ, I., DAUBER, J., THIES, C., TSCHARNTKE, T. and WOLLERS, V. 2005. Landscape context of organic and conventional farms: Influences on carabid beetle diversity. Agriculture, Ecosystems \& Environment, 108(2): 165-174.

RODRÍGUEZ, E., FERNÁNDEZ-ANERO, F. J., RUIZ, P. and CAMPOS, M. 2006. Soil arthropod abundance under conventional and no tillage in a Mediterranean climate. Soil \& Tillage Research, 85(1-2): 229-233.

ROY, S., ROY, M. M., JAISWAL, A. K. and BAITHA, A. 2018. Soil arthropods in maintaining soil health: Thrust areas for sugarcane production systems. Sugar Tech, 20(4): 376-391.

RÜDISSER, J., TASSE, E., PEHAM, T., MEYER, E. and TAPPEINE, U. 2015. The dark side of biodiversity: Spatial application of the biological soil quality indicator (BSQ). Ecological Indicators, 53: 240-246.

SCHON, N. L., MACKAY, A. D., HEDLEY, M. J. and MINO, M. A., 2012. The soil invertebrate contribution to nitrogen mineralization differs between soils under organic and conventional dairy management. Biology and Fertility of Soils, 48(1): 31-42.

SIMON, E., HARANGI, S., BARANYAI, E. et al. 2016. Distribution of toxic elements between biotic and abiotic components of terrestrial ecosystem along an urbanization gradient: Soil, leaf, litter and ground beetles. Ecological Indicators, 60: 258-264.

STINNER, B. and HOUSE, G. J. 1990. Arthropods and other invertebrates in conservation-tillage agriculture. Annual Review of Entomology, 35: 299-318.

ŠŤASTNÁ, P. and PSOTA, V. 2013. Arthropod diversity (Arthropod) on abandoned apple trees. Acta Universitatis Agriculturae et Silviculturae Mendelianae Brunensis, 61(5): 1405-1422.

TURBÉ, A., TONI, A., BENITO, P., LAVELLE, P., RUIZ, N., VAN DER PUTTEN, W. H., LABOUZE, E. and MUDGAL, S. 2010. Soil biodiversity: functions, threats and tools for policy makers. Report for EC. Bio Intelligence Service, IRD, and NIOO.

WIEZIK, M., WIEZIKOVÁ, A. and SVITOK, M., 2010. Effects of secondary succession in abandoned grassland on the activity of ground-foraging ant assemblages (Hymenoptera: Formicidae). Acta Societatis Zoologicae Bohemicae, 74: 153-160.

XIN, X. L., YANG, W. L., ZHU, Q. G., ZHANG, X. F., ZHU, A. N. and ZHANG, J. B. 2018. Abundance and depth stratification of soil arthropods as influenced by tillage regimes in a sandy loam soil. Soil Use and Management, 34(2): 286-296.

ZELAZNY, V. F., MARTIN, G. L., TONER, M., GORMAN, M., COLPITTS, M., VEEN, H., GODIN, B., MCINNIS, B., STEEVES, C., WUEST, L. and ROBERTS, M. R. 2007. Our landscape heritage: The story of ecological land classification in New Brunswick. New Brunswick: New Brunswick Department of Natural Resources.

Contact information

Radoslava Kanianska: radoslava.kanianska@umb.sk

Jana Jad'ud'ová: jana.jadudova@umb.sk

Miriam Kizeková: kizekova@vutphp.sk

Jarmila Makovníková: j.makovnikova@vupop.sk

Bernard Šiška: bernard.siska@uniag.sk

Jozef Varga: jozef.varga@umb.sk

Nikola Benková: nikola.benkova@umb.sk 